Article

\title{
Does Transnational Experience Constrain Religiosity? Korean Evangelical Women's Discourse on LGBT Persons
}

\author{
Gowoon Jung \\ Department of Sociology, State University of New York at Albany, Albany, NY 12222, USA; gjung@albany.edu \\ Academic Editor: Jill Peterfeso \\ Received: 20 June 2016; Accepted: 26 September 2016; Published: 10 October 2016

\begin{abstract}
A large literature studies the views and discourses of Western, and especially American, conservative Christians with respect to homosexuality; only a few examine the discourse of Christians in non-Western countries, and none focuses on non-Western Christians with advanced, overseas education and careers. This paper examines the discourse of South Korean Evangelical women with overseas, educational or career experiences. I draw on 15 in-depth interviews with current and former members of a Seoul-based, Evangelical mega-church. Transnational, evangelical women show comparatively mild-minded and tolerant views toward homosexuality and LGBT persons. The women illustrated two pathways to reconcile their conflicting beliefs in conservative religion and human rights: first, the values of equity and meritocracy; and second, personal contacts with LGBT persons. This study suggests that for transnational migrants, traditional religiosity is challenged and constrained by sustained experiences in liberal, pluralistic societies.
\end{abstract}

Keywords: Christian; evangelical; LGBT; woman; discourses; transnationalism

\section{Introduction}

Most sociological and public opinion studies find increasingly liberal attitudes toward homosexuality and support for the civil and legal rights of same-sex couples [1-3]. Among other factors, religion helps explain the conservative attitude toward homosexuality $[1,4,5]$. Socio-demographic studies also find that females tend to be less homophobic than males [5], and people with advanced education are more likely to be tolerant of homosexuals [2]. However, most of the literature studies the interaction of gender, education, and religiosity in Western countries and especially in the USA; only a few examine the discourses of Christians toward homosexuality in non-Western countries (but see [1]), and practically none focuses on non-Western Christians with advanced, overseas education and careers. What are the discourses of nonwestern, evangelical, transnational women with respect to sexual minorities?

This paper explores this question using South Korea (hereafter Korea) as a case study. Evangelized by American missionaries, Korea has the largest number of evangelical Christians in East Asia (about 20 percent of the population) [6], and women make up approximately 60 percent of Christians [7]. Historically characterized by a relatively homogeneous culture, exemplified by common language, Korean ethnicity, and ingrained Confucian tradition, Korea is currently experiencing a drastic growth in its ethnic and (visible) sexual diversity. Sexual minorities, comprising about 1-4 percent of the population, have been historically invisible since differences in sexual orientation are considered to contravene "conventional family values and traditional ethics" ([8], p. 19), and to bring shame on one's family and friends [9].

The past decade, however, has witnessed dramatic shifts in the discourse of LGBT rights, particularly in the entertainment and culture industry, such as Korea's first gay comedian, Seokcheon 
Hong [8]. Right after the US Supreme Court's ruling on the nationwide right to same-sex marriage in June 2015, the annual Queer Festival in Seoul City Plaza attracted thousands of supporters and opponents-the latter mostly evangelical Protestant Christians [10]. Simultaneously, social media platforms (e.g., Facebook, Twitter) and Korean portal sites (e.g., Daum, Naver) were animated with heated debates on same-sex marriage and the queer parade.

Homosexuality and LGBT discourses in Korea are largely separated into two opposing camps: the human right discourse led by LGBT activists touts universal respect and love for lesbians and gays, whereas the traditional sin discourse of conservative (evangelical) Christians oppose deviance from biblical values and the hetero-normative family ideal $[8,11]$.

This article examines the moral discourses of ethnically Korean, evangelical, transnational women. (I define evangelicals as persons who self-identify as evangelical Christians; and transnationals as those who experienced education or careers for at least one year overseas.) I assume that evangelical lay members are not passive receptors of public media and religious discourse, but actively synthesize a wide range of discourses to create their personal moral narratives. Drawing on field-observations and in-depth interviews with 15 women who are current or former members of a large-mega church in Seoul, South Korea, I show how evangelical, transnational women explain their moral reasoning on the rights of LGBT people.

\section{Public Discourses on Homosexuality in the US and Korea}

In the US, sociological studies report that younger, female, politically liberal, more educated, and wealthier people are more tolerant toward homosexuality [2,4,5]. In contrast, traditional religion has been largely associated with intolerant attitudes toward homosexuality, and conservative evangelical Protestants remain the strongest opponents of LGBT rights (especially same-sex marriage), compared with Jews, mainline Protestants and Catholics [4,12].

Religious affiliation, frequency of church attendance, and biblical doctrine influence views toward homosexuality $[4,13]$. Conservative Protestants show frequent church attendance and exposure to moral teachings, and believe that the Bible is "the literal word of God" [14], which contributes to discourses of sin and absolute morality [4,15].

In Korea, a popular majority (59\%), regardless of religious affiliations, agrees that homosexuality should not be accepted by society [16]. This conservative sentiment explains the strong opposition to social recognition and legal rights for LGBT persons. The political opposition is spearheaded by Korean evangelical Christians, who espouse an even more uniformly conservative, religious discourse than American evangelicals. Evangelized by American missionaries in the early 20th century, Korean Christians developed their faith based on "the emotional spirit-filled, bible-centered devotionalistic, and evangelical-middle class ideology" ([17], p. 392). Utilizing this ideology as a template for development in the 1980s, Korean Christians and their churches have developed a strongly conservative theology $[17,18]$.

Korean Christians and other social conservatives, however, are challenged by a growing, visible movement for LGBT rights [8,11]. While LGBT activists are the lead actors, the younger generation in Korea has shown to be increasingly supportive of LGBT rights. General acceptance of homosexuality in South Korea increased from 18 percent (2007) to 39 percent (2013), with 71 percent support among the youngest generation (age 18 to 21) [16]. A total of $83 \%$ of the student electorate at Seoul National University, the country's top-ranked university, voted for the first-ever, openly lesbian university student body president, Kim Bo-mi (23): this was the largest vote in the past 18 years [19].

Several factors explain young people's individualistic and progressive understanding of human rights. First is an increasing flow of globaleducation and travel. Korea $(63,710)$ has ranked third in sending students overseas to the US, following the much bigger countries of China $(304,040)$ and India $(132,888)$ in $2014 / 15$ [20]. It is common for Korean students to aspire to overseas education in the US "to become cosmopolitan elites and gain more privileged capitals such as English skills, cosmopolitan lifestyle and worldviews, and larger network with foreigners" ([21], p. 120). While overseas students 
are more likely to interact with ethnically and (visibly) sexually diverse persons, they are also exposed to different, more liberal perspectives, worldviews, and attitudes. Contact theories suggest that repeated and meaningful intergroup contacts diminish prejudice and enhance mutual tolerance and understanding [22,23]. A major determinant of tolerant changes among Canadian university students is increased contact with homosexuals [24]. Altemeyer (2002) stated that one's personal experiences affect one's attitudes, and contact with homosexuals has a "magical capacity" to change one's ideas. Second, the prevailing discourse among Korean young adults is the liberal, Western ideology of equity, human rights, and meritocracy. They believe that the ideal society should provide equal rights and opportunities.

\section{Transnational, Evangelical Knowledge Workers}

Sociologists of religion have investigated the relationship between religion, class, and political views. A key factor is the rise of new-class groups since the mid-twentieth century $[15,25,26]$. New-class groups are "knowledge workers" who work with complex information, such as professionals in academia, journalists, and government managerial workers. Religious knowledge workers are likely to distance themselves from traditional moral values to adapt better into secular workplaces, such as the government and knowledge production industry. Wuthnow (1993) [25] assumed that rising education among evangelicals should lead them away from traditional religion. Schmalzbauer (1993) [26] claimed that intellectual evangelicals tend to be more liberal on civil rights such as gender roles and abortions while remaining conservative on sexuality. The research implies that evangelical knowledge workers may bring more complex, sophisticated attitudes and discourses on diverse social issues, particularly LGBT persons. These educated believers with cultivated manners and liberal ideas may bring a "civilized temperate tone" to discourses on homosexuality.

Building on this framework, I pay attention to emerging, transnational actors originating from Korea, who have Western education or professional work experiences and who sustain social networks in foreign countries. Scholars of the internationalization of higher education claim that overseas students promote the circulation of global values and ideologies across territorial boundaries [27-29]. Asian students gain cultural capital such as cosmopolitan identities, practical language skills, sense of humor, and cultivated attitudes of open-mindedness and gentleness [21,29-31]. Furthermore, "transnational businessmen" or "cosmopolitan professionals" [32,33] tend to have "outward-oriented global rather than inward-oriented local perspectives on most economic, political, and cultural ideology issues" ([33], p. 20).

This transnational group tends to be more Westernized, and as such are non-hierarchical, individualist-liberals rather than Confucian-oriented, hierarchical, social conservatives. They are an important group who may contribute to more tolerant, pluralistic discourses and politics in the homeland. In this paper, I explore how transnational, evangelical women from Korea reconcile traditional sin discourse with a liberal-equity discourse supporting LGBT rights. Another question is whether liberal education and career experiences can overcome the influence of religious upbringing. I expect that international education and overseas career experiences correlate with liberal attitudes and tolerance toward homosexuality and LGBT rights, but the pathways that lead to reconciliation may be complex.

\section{Data and Methods}

This paper draws on my larger research project on Korean evangelical women. For over seven months (June 2015 to December 2015), I interviewed current and former members of a Seoul-based mega-church (World Vision Church) and conducted field observations in several of its ministries. World Vision Church (WVC) represents the largest religious tradition (Christianity) in South Korea, making up about 28 percent of the population [7]. Established in 1986, WVC is a mainstream evangelical Protestant megachurch in Korea, with chapters in Japan, USA, and other countries. Most members come from the middle-class. Under the slogan "2015 Go Lower", World Vision 
Church expanded their mission work for social justice toward diverse, marginalized groups, such as divorcees, disabled, and migrants. For instance, the 2015 Korean Diaspora Mission Conference was held on 27-29 September 2015 to reach out to Chinese Korean (Joseonjok), Russian Koreans (Goreoin), and Korean Americans (Gyopo) residing in Korea. The Ansan Onnuri Mission Center aims to provide unique services for migrant, manual workers living in the ethnic enclave of Ansan (near Seoul).

Interview data helped me to understand the interview subject's personal interpretations of religious symbols and meanings and the integration of their beliefs with everyday activities. My interviewees narrated the interpersonal dialogues that they exchanged with their intimate friends, family members, and colleagues. They also addressed dominant media discourses. As internet users, they shared valuable accounts and impressions that they gained from online communities. In fact, discourses are composed of disagreement, challenges, and interpretation about beliefs and ethical conditions. Therefore, I attempted to ask how these women internalize and challenge the largely supported public discourses. Their moral discourses are not the sole product of decoding and encoding of religious scripture, but are rather the compounded process of the Bible, mainstream/social media, and their foreign experiences.

I interviewed mostly those who were college-educated and between the ages of 20 and 39. To recruit interviewees, I combined purposive and snowball sampling. I recruited members from two specific Korean ministries, "university student ministry" and "1.5 generation adult ministry". I also included a few members from other foreign language ministries who voluntarily participated in the interviews. I selected the two ministries based on theoretical interest and personal access. I have some formal and informal networks with the university student ministry, so I could easily contact friends and acquaintances and recruit interview volunteers with their recommendations. Also, the 1.5 generation adult ministry was selected because more than sixty percent of the members are composed of overseas students and internationally educated young returnees. Most members are socioeconomically wealthy and bilingual speakers.

Interviews were conducted in Korean or English. Given the frequent overseas travels of my sample, I used online communication tools such as Skype or Kakaotalk (a Korean chatting application). I chatted online with people who were unavailable for face-to-face interviews in Seoul. Most of the interviews took place in churches, cafés, or homes, depending on the availability of interviewees. With the agreement of interviewees, interviews were audio-taped and transcribed. The interview guide consisted of six parts: (1) personal life history, mostly about international education, career paths, and foreign life experiences; (2) religious journey, personal practices and group activities; (3) how their gender affected their life story; (4) personal attitudes and views toward LGBT persons; and (6) thoughts on social and legal rights of LGBT individuals. Each interview was conducted for 1 to 3 $\mathrm{h}$ and a background information sheet was used to collect basic demographic information (e.g., age, nationality, occupation, and education).

I also implemented multi-site field observations of World Vision Church. I attended Sunday services in several ministries, mostly located in the main World Vision Church building (Gangnam district of Seoul). For four months, I regularly attended Sunday services (11 a.m. to 1 p.m.) of the 1.5 generation ministry and their small group meetings ( $2-3 \mathrm{~h}$ long discussions and sharing about weekly Bible study). The small group meetings usually took place in cafés after communal lunches; small group activities are one of the important characteristics of Korean megachurches to minimize the anonymity among members and to develop fellowship. Members discuss weekly Bible verses and their implications for everyday life struggles at home or work. As an insider to the small group meetings, I also shared my everyday life challenges. By doing so, I attempted to look closely at the processes of constructing views toward LGBT persons and of reconciling competing religious-moral and liberal-equality discourses.

This paper draws specifically on in-depth interviews with 15 women who were current or former members of WVC. They reported overseas education or career experiences in North America, Europe, and India. Nine women were permanent "returnees" to Korea, and six women were "migrants" 
currently living in foreign countries. The returnees were current WVC members in Seoul. Migrants were former WVC members: half regularly attended local, ethnic Korean churches overseas and the other half sporadically attended Korean or American churches.

\section{Discourses of Evangelical Women toward LGBT Persons}

Most of the young, transnational, evangelical women expressed personal respect and sympathy toward sexual minorities. An example is Yeonjoo (returnee), who graduated from a top Korean university and even earned a master's degree with internship experiences at an international organization in Paris. While studying abroad for a semester in California during college, she became close to an American friend who "came out" to her many years later. She presented a mild, tolerant attitude toward sexual minorities.

I think I can get along with them well (if my colleagues at workplace or friends in church come out to me). I had an experience before. In the beginning, it was shocking, but it did not matter much because I had a good relationship with my friend as a friend from the beginning. So, I could accept it. After having that experience, I feel like I can get along with them and treat them well if any people come out to me (Yeonjoo, 31, Banker).

Jiyeon (returnee), who lived in India for a year for student exchange in her early 20s explained:

"Well, if someone at church or colleague at workplace come out to me, I would rather feel appreciated. It means that the person trusts me. Although that person can be a lesbian, she would not harm me...I do not think that my religious identity, being a Christian, would be a big problem."

Majoring in computer science, she was an active member of World Vision Church, volunteering for many different positions. "I have worked for many positions including small group leader, worship team member, and technical support team." Also, said Daeun, a migrant currently living in the Mid-west region of the US: "Of course, I can get along with LGBT". Evangelical Christians distinguish between the morality (i.e., sinfulness) of homosexuality and the civil rights of LGBT persons [34]. Yeonjoo, who worked in a renowned bank, explained that she would be willing to hire a LGBT applicant if she ran her own company. "Yes. If LGBT people are in the same conditions and they are capable of carrying out the position." Jiyeon also supported the idea. "If someone applies for my company, would I hire that person? Since I do not know that person, I would say that having a [romantic] relationship at the workplace is not allowed. I would say okay under the condition that being in a relationship at the workplace is prohibited..." Jiyeon, who studied abroad in India and enjoyed traveling, but was currently employed as a computer designer in Korea, supported the equal treatment and social recognition of LGBT persons, despite her religious beliefs that homosexuality was sinful.

Daeun, a transnational migrant who lived in Wisconsin (USA) for nearly four years, explained that one's sexuality should not be a barrier to employee hiring and promotion. She supported other rights, such as hospital visitation. "Although changing the law is a big issue, I think it would be good for gay couples to go to the hospital together and visit partners". In the US, the case of Janice Langbehn, who was denied visiting rights to her same-sex partner at a hospital in 2007, raised social awareness of the vulnerability of same-sex couples and discrimination in medical decision and health care [35]. In South Korea, a sensitive and controversial issue is the employment of homosexual teachers at English private schools. A mainstream newspaper reported that parents are concerned about untrustworthy, native English teachers who could be drug users or homosexuals [36]. Daeun even upheld the progressive position to send her kids to a private school that employed homosexual teachers.

"In the US, we cannot demand heterosexual teachers as parents when we send our kids. It does not make senses. In fact, drawing a line for my kids and dividing heterosexual and homosexual is not right and educationally good for kids. In the formal public spaces, 
we need to guarantee the equal rights and support their rights. Everyone must have equal social rights" (Daeun, 29, Graduate student).

Religious women's acceptance of the social rights of LGBT persons encompass employment, promotion, and hospital visits. Their narratives largely characterize a non-discriminatory attitude with equal rights and opportunities for all members in society.

\section{Conflicts between Religious and Human Right Discourses}

Despite their tolerant discourses toward LGBT persons, the thought process of evangelical women is complex. Hyeyoung (migrant), a happily employed professional educator in New York City, shared her inner conflicts. "I am a Christian, and it is a sin according to the Bible. Sin is sin...but I do not have a right to blame, condemn, and judge them...I do not have an answer for that...I have moral conflicts sometimes in my workplace. We have gay employees in my school...I have sometimes inner conflicts when I hang out with them. One night after my gay friend's birthday party, he invited me to go to a gay bar together. The next day was Sunday, and I had to stand on a stage as a choir member during the worship..." She pondered upon her friend's request, but did not accompany him.

It is clear that her religious values were challenged. Hyeyoung said,

"Concerning the human right, we are now living in the era when the death penalty system punishing murders is abolished...then how can we talk about punishing the sexual minorities? Let's say I run a coffee shop and one gay man come in and he wants to buy a cup of coffee, then I do not think it is right to discriminate the gay customer...I cannot do anything in the situation."

In fact, her coffee shop example resonates with the heated public discourses on the tension between LGBT rights and religious freedom (specifically the rights of religious conservatives to refuse services to LGBT persons). Her confusion between her religious and professional identity demonstrates the conflicting discourses on LGBT in the larger American society.

Hyeyoung typifies the dilemma of internationally educated women, as they try to preserve dual ideologies (religious, liberal) and walk a fine line between contrasting discourses. Her entire life, she has been exposed to an evangelical ideology which stresses biblical literalism; but her current life in a new city challenges her prior ideology. Liberal, progressive ideas and human rights discourse dominate metropolitan New York City and cause her to doubt her values. As a teacher, she had an important moment to confront the inner conflict as a religious believer and an impartial liberal citizen and teacher: "There was a student who openly identified as a gay. In his case, everyone has known that. He comes to school with his Barbie doll backpack."

Concerning her reaction, she seems to be devoted and responsible to her current job. Hyeyoung recounted how she wants to respect and protect her students' identities rather than preserve her religious identity: “They are all my students. There was an event period for the LGBT. We made a rainbow ribbon, and teachers were supposed to put it on our chest with a pin, symbolizing the support for the LGBT rights. At first, I did not know what to do and did not want to demonstrate [support to] either [pro- or anti-LGBT rights] party. I do not know either party well...but I just put it on my chest." Her school is a charter school known for a sizable African- American student population, and Hyeyoung understood that Black gays are shunned in the Black community, and culturally less accepted than White gays. She said, "I did not like that my Black male students could feel that they are not accepted and welcomed...They are situated in a disadvantaged position." Her support for students reflected her commitment as a teacher, love for her students, and devotion to the position. Overall, Hyeyoung does not remain a static, dogmatic Christian believer, but lives as a warm-hearted person in her daily life, exposed to human rights and equity discourses in the US.

Other women, usually with an international background, also illustrate this complex configuration of two identities. They initially voiced their religious beliefs and then revised their firm viewpoints. Jiyeon said, "I am a Christian, and I think that homosexuality is a sin." Initially, Evangelical women 
like Jiyeon overtly conformed to the discourse on sin, displaying their biblical literalism. Yet, Jiyeon's later account showed a more refined and cultivated way of understanding the Bible. "But we are all sinners if we think like that...in terms of that relationship with that person...I do not know well...if that person came out to me, it means that we are already friends...so, I will be friends with the person." Jiyeon emphasized that we should know how to respect others' freedom and personal autonomy as an educated citizen. The civility required women to cooperate and communicate with others in a society. Narratives of Canadian students showed that they accepted the ideology that one should hate the sin of homosexuality, but love the sinner. The participants' accounts of their interactions with gays implied that the way they treated gay persons changed after discovering their sexuality [37].

Yeonjoo conveyed a similar sin discourse as Jiyeon.

"Sin is sin. According to the Bible, homosexuality is not right, and that is clear because (evidences from) our biological structures and statements in the Bible are so obvious. If it was thought of as not clear enough, then it would raise debates, but the Bible is too clearly stating on the issue."

The claim that homosexuality is sin was never challenged by my respondents. For Yeonjoo, the biblical teachings are sacred. "Because once I negate it, it means that I reject the Bible, so I cannot reject the fact that homosexuality is a sin." Yet, Yeonjoo developed a similar approach to homosexuality as Jiyeon: "We cannot weigh the relative seriousness of sin. What is more evil between stealing and being homosexual...this is not a matter that I can make a judgment. God can only detect and judge. This is not an issue that I can conclude or judge. There are other sins like being bitter, but heterosexuals' hatred and homosexuals' sexual identity... which sin is more serious? How can a person discern between right and wrong? I cannot but accept the fact that homosexuality is a sin...but it is not righteous to view homosexual people with a strange look or so." Although the perspective of biblical literalism is not abandoned, Yeonjoo's understanding does not necessarily draw a discrete line between heterosexuals and homosexuals. Indeed, her narrative presents a retreat from the prevailing, moral absolutism of Korean evangelical Protestants. Alternatively, her discourse mirrors the egalitarian notion that we are all sinners, not only gays. In Jewell and Morrison (2012) [37], participants were exposed to the teaching that homosexuality is inappropriate, but also that one should "love thy neighbor." The participants reconciled these two teachings by claiming that it is the morality of homosexuality that they are opposed to and not the actual people who are gay.

Minjeong (migrant), an office worker in a business in New York City, also rejected any unsympathetic condemnation of gays.

“Well...I am also just a person. I have weaknesses. We are all sinners...I am also an ill person, but they receive more spotlight socially. If there is something that I think we need, it is to embrace others, I think that we need to start with that... we do not have the right to persecute and stigmatize because 'they are wrong', but instead we should focus on going forward and take care of the parts that they have been hurt. I think that that is what Christianity has to focus. What Jesus Christ did in this world in the beginning was that kind of work. He cured prostitutes, fed and accommodated the sick, and understood marginalized people's side in the society....In God's eyes, they must be the same sinner as other normal people. In that respect, I question what is truly different between a gay person and I. How can I condemn and criticize them?"

Minjeong did not give moral supremacy to Christians, but admitted the universality of sin for all Christians and acknowledged the autonomy of one's choice in choosing sexual identity. Internationally educated and experienced women endured the dissonance of clashing identities and confronted the self-doubt, confusion, and disorientation. Yet, most interpreted homosexuality in a sophisticated, creative way; some emphasized civility as educated, urban professionals in the USA, whereas others showed a conditional, revised perspective on the traditional sin discourse. They rejected the hostile interpretation of homosexuality among evangelical Christian leaders in Korea. 


\section{Pathways to Reconcile Conflicting Discourses}

Women with transnational experience are more likely to generate a tolerant attitude toward LGBT persons in discussing individual interaction and social rights. Yet, the processes to decide their positions were neither simple nor uniform. In this section, I present two pathways to reconcile their conflicting perspectives and to construct tolerant discourses. The first is their belief on equity and meritocracy, and the second is meaningful contacts with LGBT persons.

While immersing themselves in a liberal, egalitarian, and Western ideology, transnational, evangelical women morphed into supporters of equity, human rights, and meritocracy. They believe that the ideal democratic society should guarantee the provision of equal rights and opportunities. Their belief and support for the equity of sexual minorities is largely shaped by advanced education and related information gained in foreign countries, particularly in the United States.

Daeun, who does not mind sending her kids to gay teachers, ascribed the reasons for her overtly liberal views to overseas education experiences. "I was educated here [in the USA], and it had a huge effect on me. Books that I have read all dealt with those contents about equality." As her study concentration was in art education for minorities, she was influenced by her study field and progressive political ideology. As a devout Christian back in Korea, she had attended church her entire life with her family, but she had never heard of anything about homosexuality and LGBT persons. After graduating from one of the top universities in Korea, she migrated to the US with her husband for his doctoral study. Her travel to the US accelerated a liberal, political critique of her religious traditions. Daeun critiqued the scandals of senior pastors and corruptions of large- scale churches in Korea, as well as the authoritarian, hierarchical church culture.

Moving to the US opened her eyes in many ways. "It has been firmly solidified while studying in the US," Daeun explains, "I think that I need to respect those minorities' choices as they themselves decide." Her expression is not pitiful or pathetic toward them, but more egalitarian as equal citizens in society. She said, "If I want to be accepted, we need to embrace our difference." The information that she gained in a foreign environment helped form her viewpoints as well. She stated that overt or subtle discrimination in workplaces and public institutions, including schools, universities, and hospitals, are legally prohibited in Wisconsin, where she was living. She was well informed about the liberal policies and programs in her city (Madison, Wisconsin).

Meanwhile, some women expressed support for not only equal opportunities, but also impartial and fair rewards based on performance. A transnational returnee (Yeonjoo) said, "I work in a [Korean] bank, and it is a very conservative and competitive organization...Korean people hate people who expect and demand something for free. People hate free riders. Society is getting more hard-hearted and tough. I grew up while receiving the best education given to only one percent of the population and I am still struggling to survive." The challenging economic structure reinforces women's support for equal job opportunities and fairness in performance rewards. Many women who were working in companies emphasized whether a person is capable of carrying out the position. Although they were born as Christians, their working experiences in secular society pushed them to cherish work fairness and to flexibly prioritize between morals and work. Evangelical women support the notion that one's legitimacy in the workplace or society should be based on one's capability and performance. This sentiment strengthened when they returned to Korea after foreign educations and careers and readapted into a competitive, domestic job market. This may lead women to withdraw from strictly biblical-moral narratives, but to support equity and human right discourses linked to a merit-based system.

Furthermore, transnational migrants, who have lived in foreign countries for either education or career, experienced more interactions with LGBT persons. Hyeyoung, currently working in a New York City high school, typified a transnational migrant with a dense, local social network. She earned her bachelor's degree in an elite university in Korea, but started her foreign experiences in her early 20s through an exchange program in the US. Graduating from a Protestant mission school in Seoul, she was a devout Christian who actively volunteered as a group leader in her church for five 
years. While residing in New York City, she was exposed to an overtly liberal, sexually diverse culture. She explained, "We have two gay employees, one teacher and one office worker, at my high school workplace right now. One is single and the other one cohabitates with a boyfriend."

Indeed, her actual friendship with LGBT persons is not only regular and frequent, but also delightful and gratifying. "I see them every day (like five days per week)...It does not bother me. I did not know that they were gay. I get along with them well. I am fine with that. Nothing bothers me. I am personally close to gays... They all have a good personality. I even know my coworker's boyfriend well too. I hang out with them often." People feel less threatened after developing personal contacts with members of different groups. It helps when the interaction is repeated, sustained, and between individuals of equal status [22].

The personal interactions in the city enabled Hyeyoung to learn about gay subculture. Hyeyoung said, "You know the word 'radar', because there is a term called 'gay-dar'. A Gay-dar refers to the ability to distinguish one's sexual identity." She became familiar with the gay culture and vocabulary, which allowed her to be more culturally accepting of gays and lesbians. "In New York City, gays are taken for granted...if someone questions or looks down upon gay people, that person will be deemed really weird."

Minjeong, who worked in a foreign embassy in the US after graduating from a Seoul university, also presented open, egalitarian views toward social rights of LGBT persons. Minjeong lived in Washington D.C. and then relocated to New York City. Her New York neighborhood was notable for a large gay and lesbian population. She had met them in person, and one of her close friends was lesbian. "I think of them just the same as heterosexual couples. A gay couple is very clearly within the boundaries of common sense. There is no one who goes beyond that in New York City." She witnessed the queer parade in New York City, and expressed her impression about how it looked "normal".

Minjeong's perception of homosexuals was mostly shaped during her stay in the US "Well, when I think about them as person to person, I don't know... Personally, I think that it is their free will, and I cannot say anything judgmental. I cannot argue the right or wrong because it is their freedom." Regarding LGBT people, she said that she will welcome and accept their sexual identity.

\section{Religiosity versus Class in the Transnational Environment}

The display of women's discourses reflects the salient impact of transnational experiences. The stories of transnational migrants support the liberalizing influence of education among evangelicals [25]. Contrary to Schmalzbauer (1993) [26], who found that knowledge worker evangelicals remained conservative on sexuality, I find a nearly uniform pattern of liberal acceptance toward homosexual persons, if not the morality of homosexuality itself, among Korean evangelical knowledge workers.

Wuthnow (1993) [25] predicted that intellectual evangelicals would show a more liberal attitude and utilize social and political liberalism as a survival strategy. As a result, people within this new-class shift from a sectarian, religious attitude to a mild-minded, civilized, accommodating stance on moral issues. This study places Wuthnow's thesis in a non-Western, transnational context. Given that many young, Korean evangelicals receive advanced Western education and build up overseas careers, the stories of these women offer a case study of how religiosity is challenged and revised by class factors in a transnational context.

The duality of being a conservative Christian and a citizen in a liberal-pluralist society often results in psychological conflicts. The pervasive religious discourse of Christian media and religious elites in Korea stresses the sinful nature of homosexuality [38]. The leading Korean Christian newspaper, The Christian Daily, featured a statement from American evangelical Matt Barber: "God's Word, throughout both the Old and New Testaments, specifically denounces as evil rising to the level of 'a detestable sin' all same-sex sexual conduct" [39].

The conservative religious discourse is countered by a liberal human rights discourse, emerging in Korea but prevalent among knowledge workers in the USA. The liberal discourse powerfully 
influences transnational, evangelical women during their sojourn in the USA. The women acquire diverse, predominantly liberal views, information, and experiences associated with sexual minorities, and therefore generate more conditional, pluralistic, and complex discourses, rather than purely dogmatic religious views.

\section{Discussion and Conclusions}

This paper explores the discourses of transnational, religious women toward homosexuality and LGBT persons, and explains the pathways of these discourses. Transnational, evangelical women largely present a mild-minded and tolerant view of sexual minorities' civil rights, particularly formal-legal rights in the public sphere. These include equal eligibility, opportunities, and benefits in the public and non-church spaces, including private corporate and public institutions. They uphold non-discrimination and equal opportunities in employment and job promotion and the equal rights in hospital visitation and use of health care. Nonetheless, their tolerant views and moderate support are not the simple output of overseas education, career, and cosmopolitan life experiences, but a complex personal reconciliation of conflicting identities as religious laypersons and transnationally educated elites.

The women struggle to reconcile evangelical sin discourse and progressive, pro-LGBT equity discourse. By focusing on their past life stories and narratives, I revealed two pathways as processes of reconciling the inner conflicts and shaping their ultimate discourses: first, belief in equity and meritocracy, and second, meaningful contacts with LGBT persons. Overseas education and career experiences influence them to believe in the importance of qualification, ability, and performances for professional positions at workplaces and support the merit-based system. Rather than morally judging who are the worthy members of the society, they lean toward meritocracy, fairness, and equal rights.

Second, the personal interactions of evangelical women with LGBT persons change their views toward sexual minorities. The coming out of close friends, coworkers, and acquaintances and the interaction with them influenced women to think of sexual minorities independently from their prior, conservative religious views. Furthermore, the wide social recognition and acceptance of LGBT persons in the metropolitan urban area spurred evangelical women to be more tolerant of LGBT persons; this was part of their adaptation to a liberal-pluralist overseas society.

My findings contribute to understanding the growth of liberal-pluralistic discourses among transnational Korean evangelicals. However, the results do not necessarily imply that transnational evangelicals will permanently retain their liberal views when they return to the homeland, let alone that they shall contest the prevailing, conservative discourse among Korean evangelicals. It may be that the liberal discourse of transnational evangelicals is context-specific, i.e., depends on the prevailing liberal ideology and open gay culture of American cities. South Korea lacks such conditions, at least to a similar extent, and its evangelical churches remain highly conservative in regards to sexuality. A longitudinal follow-up study of transnational women who permanently return to South Korea could reveal whether and how they voice liberal discourses in a predominantly conservative society and in evangelical church settings.

Conflicts of Interest: The author declares no conflict of interest.

\section{References}

1. Adamczyk, Amy, and Cassady Pitt. "Shaping Attitudes about Homosexuality: The Role of Religion and Cultural Context." Social Science Research 38 (2009): 338-51. [CrossRef] [PubMed]

2. Loftus, Jeni. "America's Liberalization in Attitudes toward Homosexuality, 1973 to 1998." American Sociological Review 66 (2001): 762-82. [CrossRef]

3. Thomas, Jeremy N., and Daniel V. A. Olson. “Evangelical Elites' Changing Responses to Homosexuality 1960-2009." Sociology of Religion 73 (2012): 239-72. [CrossRef] 
4. Burdette, Amy M., Christopher G. Ellison, and Terrence D. Hill. “Conservative Protestantism and tolerance toward homosexuals: An examination of potential mechanisms." Sociological Inquiry 75 (2005): 177-96. [CrossRef]

5. Ellison, Christopher G., and Marc A. Musick. "Southern intolerance: A fundamentalist effect?" Social Forces 72 (1993): 379-98. [CrossRef]

6. Lee, Timothy S. Born Again: Evangelicalism in Korea. Honolulu: University of Hawaii Press, 2010.

7. Gallup Korea. Religion in Korea 1984-2014. Seoul: Gallup Korea, 2015.

8. Yang, Junghoon. "Homosexuals and the Contemporary Gay Rights Movement in Korea: Movement Participation and Collective Identity." Master's Thesis, University of Gothenburg, Gothenburg Sweden, 2013.

9. Cho, John. "The Wedding Banquet Revisited: 'Contract Marriages' between Korean Gays and Lesbians." Anthropological Quarterly 82 (2009): 401-22.

10. Ock, Hyun-Ju. “After Long Fight, LGBT Activists Parade in Seoul." Korea Herald, 28 June 2015. Available online: http:/ / www.koreaherald.com/view.php?ud=20150628000246 (accessed on 14 September 2016).

11. Im, Yookyeong. "Communion for All: Queer Christian Citizenship in an LGBTQ-Affirming Church." Master's Thesis, Seoul National University, Seoul, Korea, 2015.

12. Reimer, Sam, and Jerry Z. Park. "Tolerance (In)civility? A longitudinal analysis of White conservative Protestants' willingness to grant civil liberties." Journal for the Scientific Study of Religion 40 (2001): 735-45. [CrossRef]

13. Beatty, Kathleen Murphy, and Oliver Walter. "Religious Preference and Practice: Reevaluating Their Impact on Political Tolerance." Public Opinion Quarterly 48 (1984): 318-29. [CrossRef]

14. Hunter, James Davison. Evangelism: The Coming Generation. Chicago: University of Chicago Press, 1987.

15. Roof, Wade Clark, and William McKinney. American Mainline Religion: Its Changing Shape and Future. New Brunswick: Rutgers University Press, 1987.

16. Pew Research Center. “The Global Divide on Homosexuality." 4 June 2013. Available online: http:/ / www. pewglobal.org/2013/06/04/the-global-divide-on-homosexuality/ (accessed on 14 September 2016).

17. Ryu, Dae Young. "The Origin and Characteristics of Evangelical Protestantism in Korea at the Turn of the Twentieth Century." Church History 77 (2008): 371-98. [CrossRef]

18. Chung, Byung Joon. "A Reflection on the Growth and Decline of the Korean Protestant Church." International Review of Mission 103 (2014): 319-33. [CrossRef]

19. Jhoo, Dong-Chan. "SNU Has First Lesbian Student President." Korea Times, 20 November 2015. Available online: http://www.koreatimes.co.kr/www/news/nation/2015/11/116_191453.html (accessed on 14 September 2016).

20. Open Doors. "2015 Fast Facts": International Students in the U.S. New York: Institute of International Education, 2015.

21. Kim, Jongyoung. "Aspiration for global cultural capital in the stratified realm of global higher education: Why do korean students go to US graduate schools?" British Journal of Sociology of Education 32 (2011): 109-26. [CrossRef]

22. Dyck, Joshua, and Shanna Pearson-Merkowitz. "The Conspiracy of Silence: Context and Voting on Gay Marriage Ballot Measures." Political Research Quarterly 65 (2012): 745-57. [CrossRef]

23. Pettigrew, Thomas F. "Intergroup Contact Theory." Annual Review of Psychology 49 (1998): 65-85. [CrossRef] [PubMed]

24. Altemeyer, Bob. "Changes in attitudes toward homosexuals." Journal of Homosexuality 42 (2002): 63-75. [CrossRef]

25. Wuthnow, Robert. Christianity in the Twenty-First Century. New York: Oxford University Press, 1993.

26. Schmalzbauer, John. "Evangelicals in the New Class: Class versus Subcultural Predictors of Ideology." Journal for the Scientific Study of Religion 32 (1993): 330-42. [CrossRef]

27. Brooks, Rachel, and Johanna Waters. Student Mobilities, Migration and the Internationalization of Higher Education. Basingstoke: Palgrave Macmillan, 2011.

28. Rizvi, Fazal. "International Education and the Production of Cosmopolitan Identities." In Globalization and Higher Education. Hiroshima: Research Institute for Higher Education, 2005.

29. Rizvi, Fazal. "Towards Cosmopolitan Learning." Discourse: Studies in the Cultural Politics of Education 30 (2009): 253-68. [CrossRef]

30. Ong, Aihwa. Flexible Citizenship: The Cultural Logics of Transnationality. Durham: Duke University Press, 1999. 
31. Sin, I. Lin. "Malaysian Students in Australia: The Pursuit of Upward Mobility." Asian and Pacific Migration Journal 15 (2006): 239-66. [CrossRef]

32. Waters, Johanna L. "'Roundabout Routes and Sanctuary Schools': The Role of Situated Educational Practices and Habitus in the Creation of Transnational Professionals." Global Networks 7 (2007): 477-97. [CrossRef]

33. Sklair, Leslie. The Transnational Capitalist Class. Oxford: Blackwell, 2001, vol. 306.

34. Kite, Mary E., and Bernard E. Whitley. "Sex Differences in Attitudes toward Homosexual Persons, Behaviors, and Civil Rights A Meta-Analysis." Personality and Social Psychology Bulletin 22 (1996): 336-53. [CrossRef]

35. Riou, Garrett. "Hospital Visitation and Medical Decision Making for Same-Sex Couples." Center for American Progress, 15 April 2014. Available online: https://www.americanprogress.org/issues/lgbt/news/ 2014/04/15/88015/hospital-visitation-and-medical-decision-making-for-same-sex-couples/ (accessed on 14 September 2016).

36. Sim, Hee Su. "Need for The Share of Information among Private Schools to Hire Reliable Native Teachers." Segye Ilbo, 22 January 2009.

37. Jewell, Lisa Margaret, and Melanie Ann Morrison. "Making Sense of Homonegativity: Heterosexual Men and Women's Understanding of Their Own Prejudice and Discrimination toward Gay Men." Qualitative Research in Psychology 9 (2012): 351-70. [CrossRef]

38. Brew, Paul R. "Values, Political Knowledge, and Public Opinion about Gay Rights: A Framing-Based Account." Public Opinion Quarterly 67 (2003): 173-201. [CrossRef]

39. Barber, Matt. "Bible, Human History and Biology Incontrovertible: Homosexuality Is Wrong." CNS News, 4 April 2016. Available online: http://www.cnsnews.com/commentary/j-matt-barber/bible-humanhistory-and-biology-remains-incontrovertible-homosexuality (accessed on 14 September 2016).

(C) 2016 by the author; licensee MDPI, Basel, Switzerland. This article is an open access article distributed under the terms and conditions of the Creative Commons Attribution (CC-BY) license (http://creativecommons.org/licenses/by/4.0/). 